NBER WORKING PAPER SERIES

\title{
PRICE REACTIONS TO DIVIDEND \\ INITIATIONS AND OMISSIONS: \\ OVERREACTION OR DRIFT?
}

\author{
Roni Michaely \\ Richard H. Thaler \\ Kent Womack
}

Working Paper No. 4778

\section{NATIONAL BUREAU OF ECONOMIC RESEARCH \\ 1050 Massachusetts Avenue \\ Cambridge, MA 02138 \\ June 1994}

The authors thank the seminar participants at Cornell, Chicago, and Illinois plus Eugene Fama, Steven Kaplan, Charles Lee, and Jay Ritter for helpful comments. We also benefitted from the comments of the anonymous referee and Rene Stulz, the editor. Errors are ours alone. This paper is part of NBER's research program in Asset Pricing. Any opinions expressed are those of the authors and not those of the National Bureau of Economic Research. 
NBER Working Paper \#4778

June 1994

\title{
PRICE REACTIONS TO DIVIDEND \\ INITIATIONS AND OMISSIONS: OVERREACTION OR DRIFT?
}

\begin{abstract}
Initiations and omissions of dividend payments are important changes in corporate financial policy. This paper investigates the market reaction to such changes in terms of prices, volume, and changes in clientele. Consistent with the prior literature we find that short run price reactions to omissions are greater than for initiations $(-7.0 \%$ vs. $+3.4 \%$ three day return). However, we show that, when we control for the change in the magnitude of dividend yield (which is larger for omissions), the asymmetry shrinks or disappears, depending on the specification. In the 12 months after the announcement (excluding the event calendar month), there is a significant positive market-adjusted return for firms initiating dividends of $+7.5 \%$ and a significant negative market-adjusted retum for firms omitting dividends of $-11.0 \%$. However, the post dividend omission drift is distinct from and more pronounced than that following earnings surprises. A trading rule employing both samples (long in initiation stocks and short in omission stocks) earns positive returns in 22 out of 25 years. Although these changes in dividend policy might be expected to produce shifts in clientele, we find little evidence for such a shift. Volume increases, but only slightly and briefly, and there are no important changes in institutional ownership.
\end{abstract}

Roni Michaely

Johnson School of Management

Malott Hall

Cornell University

Ithaca, NY 14853

Kent Womack

Johnson School of Management

Malott Hall

Cornell University

Ithaca,NY 14853
Richard H. Thaler

Johnson School of Management

Malott Hall

Comell University

Ithaca, NY 14853

and NBER 
When a firm initiates the payment of a regular dividend, or omits such a payment, the firm is making an extremely visible and qualitative change in corporate policy. What effect do such abrupt changes have on returns? We investigate both the immediate (three-day) reaction to initiation or omission announcements as well as long-term postannouncement performance.

Consistent with prior studies of dividend omissions [Healy and Palepu (1988)], and initiations [Asquith and Mullins (1983) and Healy and Palepu (1988)], we find that omission announcements are associated with a mean price drop of about $7 \%$, and initiations are associated with a price increase of over $3 \%$. There are several aspects, however, of the short-run price reaction to the announcements of initiations and omissions that are investigated here. First, are the reactions proportional to the change in yield associated with announcement, or does the announcement have a fixed effect? ${ }^{1}$ Second, does the market treat initiation and omission announcements asymmetrically? Are omissions more serious events? To investigate this issue we control for the change in yield, which is, on average, much greater for omissions than initiations. Third, are those omissions when the cash dividend is replaced by a stock dividend treated differently by the market?

Of greater interest are the long-run effects of initiation and omission announcements. Are there subsequent excess returns after the market has had an initial chance to react to the announcement of a change in dividend policy? There are three reasons why one might expect significant excess returns in years following the announcement.

First, many authors [e.g., Ball and Brown (1968), Foster, Olsen, and Shevlin (1984), and Bemard and Thomas $(1989,1990)]$ have found evidence for what has come to be called "post earnings announcement drift". The finding is that when firms make

1 Previous studies have documented and formalized the notion that dividends may convey information about future cash flow. E.g., Bhattacharya (1979), Miller and Rock (1985), Watts (1973), Aharony and Swary (1980), and Ofer and Siegal (1987). 
surprising quarterly eamings announcements, prices continue to move in the same direction for the next three quarters, especially on the days surrounding the next two quarerly eamings announcements. Since dividend omissions and initiations are similar, in some ways, to earnings surprises, one might expect a similar drift in prices following the change in policy. That is, prices of furms that omit a dividend would drift down, after the immediate reaction to the omission, and prices of firms that initiate would drift up. Post earnings announcement drift can be interpreted as a type of underreaction. The initial price move is insufficient, leaving room for a subsequent drift.

A second literature, however, provides some reason to expect exactly the opposite pattern of prices. Numerous studies have found evidence for overreaction or mean reversion in prices. For example, De Bondt and Thaler $(1985,1987)$ document that those firms which exhibit the most extreme price performance over long time periods (such as 3-5 years) tend to display mean reverting excess returns in the subsequent time period. (This tendency is stronger for losers than for winners.) Similar results have been obtained by many other researchers in other markets and for different time periods. ${ }^{2}$ One study is directly applicable. Bremer and Sweeny (1991) studied all the one day price changes of greater than $10 \%$ for a sample of large NYSE companies. They found that over the next six days, the prices of the losers rebounded by about $30 \%$ of the original loss. Once again there was no rebound for the winners. De Bondt and Thaler characterize these results as evidence of overreaction to the accumulation of bad news during the formation period. One might expect a similar reaction to the omission of a dividend, especially since firms that take this action are likely to be long-term losers. The overreaction literature would also suggest that the price patterns might be different for omissions and initiations, with a rebound only for the omissions. ${ }^{3}$

2 See De Bondt and Thaler (1989) for a review as well as the more recent contributions of Chopra, Lakonishok and Ritter (1992) and Lakonishok, Shleifer, and Vishny (1993).

3 It is still possible that a few furms that had previously paid a dividend enter our sample. For example, a firm that had paid a dividend on NASDAQ but was not paying one when listed on NYSE or AMEX would meet our criteria when it resumed paying a dividend. 
A third reason why one might expect excess returns following a dividend initiation or omission is the likelihood that such actions could cause a change in the type of stockholders owning the company, a clientele effect. Changes in clientele among individual stockholders may occur because some individual stockholders dislike cash dividends for tax reasons, while others may prefer the cash payments (Black and Scholes (1974), and Shefrin and Statman (1984)). Similarly, some institutions may either have a preference for dividends or be required by charter to own stock only in dividend paying companies, i.e., various "prudent man" rules. For all these reasons, it is plausible to suppose that dividend initiations and omissions may create a change in ownership. Of course, this does not necessarily imply that there will also be predictable excess returns. In an efficient market, prices will quickly adapt to a new equilibrium, even if the change in clientele is not instantaneous. That is, the new equilibrium price will reflect the eventual supply and demand after adjustments in ownership are complete. Nevertheless, if changes in ownership are gradual, price changes might be gradual too, with prices drifting as a result of "price pressure". ${ }^{4}$ The existence of clientele effects does not make a crisp prediction about long-term price movements, but offers another reason to investigate this question.

Two earlier papers offer some hints as to how our investigation will turn out. First, Charest (1978) srudied the price reactions to announced changes in dividend policies. His events included all changes in dividend payout of 10 cents per share or more, not just initiations and omissions. Although there are some limitations to his study because of the time at which it was written (for example, he does most of his analysis with monthly data for the time period 1947-1968), Charest finds small but significant drift after dividend changes. That is, excess returns are positive in the months following the announcement of a dividend increase, and excess returns are negative in the months following the announcement of dividend cuts. More recently, Christie (1990) studied the

4 For similar arguments, see Shleifer (1986) and Harris and Gurel (1986). 
returns of dividend and non-dividend paying stocks. He found that non-dividend paying

firms earn negative size adjusted returns. Although most of his paper combines firms that have omitted a dividend with those that have never paid a dividend, he does report one analysis for omitting firms that shows negative returns relative to a size-matched dividend-paying sample. The results we present are consistent with both of these earlier efforts.

The outline of the paper is as follows. Section I begins with a summary of our data and some descriptive statistics about the sample of initiations and omissions. In Section II we then examine the short-run market reactions to both types of events in the three days surrounding the announcement. Section III contains the long-term return results. Section $I V$ checks the robustness of the long-term excess returns. Section $V$ investigates clientele effects and Section VI offers some conclusions.

\section{Sample Selection and Methodology}

\section{A. Inipiation Sample Selection}

Using the CRSP tapes, we collect all NYSE/AMEX companies that initiated dividends during 1964-1988. We define a dividend initiation as the first cash dividend payment reported on the CRSP Master File. (Re-institution of a cash dividend is not considered a dividend initiation for our purposes). The following criteria were established for inclusion in our initiation sample:

(1) The company must have been traded on the NYSE or AMEX for two years prior to the initiation of the first cash dividend. This criterion was chosen for two reasons. It helps us to select an adequate pre-event period for comparison of returns and it eliminates new listings on the NYSE or AMEX that had been paying dividends while on NASDAQ or on another exchange before being listed. While this criterion excludes a substantial number of potential initiation candidates, we feel that it protects the purity 
of the remaining initiation events by eliminating candidates that had listed or had gone public on the NYSE or AMEX with some pre-announced intention to pay dividends in the near future.

(2) All closed-end funds and all companies paying monthly dividends were excluded from the sample.

(3) All foreign companies (usually traded in ADRs) were excluded from the sample, since payment conventions in other countries sometimes make checking the periodicity or regularity of payments difficult.

The resulting sample contains 561 cash dividend initiation events. The initiation declarations are widely spread over 25 years, as shown in Table 1, Panel A. The sample shows a positive correlation $(\rho=+.44)$ with percentage changes in aggregate U.S. corporate profits (as reported by the Federal Reserve Board). Also shown in Table 1 are the size distribution (Panel B) and price range (Panel C) of the initiation sample. Each year we divide the entire sample of NYSE stocks into deciles according to market capitalization at the beginning of the year. Then, each stock that initiates a dividend in that year is placed in the appropriate category. The table shows the frequency distribution across deciles of our initiation sample. Firms that initiate dividends are some what smaller than the NYSE/AMEX universe. Although only $21.5 \%$ of these firms are in the smallest two deciles, only 5\% are in the largest two deciles. The median is in the 4 th decile. The median price per share of initiating firms is approximately $\$ 10$, as reported in the first row of Panel $\mathrm{C}$.

\section{B. Omission Sample Selection}

Unlike initiations, declarations of dividend omissions are not recorded on the CRSP tapes. The CRSP files contain announcement dates for dividend declarations, but no dates for the subsequent omissions of regular or irregular payouts. Hence, our sample construction strategy was to select from the CRSP Master File those companies that had existed on the NYSE or AMEX for more than one year and had paid regular, periodic 
cash dividends and then omitted such payments during 1964-1988. Specifically, for a company's dividend record to be considered as a potential omission event in our sample, one of the following must have occurred:

(1) The company declared at least six consecutive quarterly cash payments and then paid no cash payment in a calendar quarter.

(2) The company declared at least three consecutive semi-annual cash payments and then paid no cash payments in the next six months.

(3) The company declared at least two consecutive annual cash payments and then paid no cash payments in the next year.

The above search identified more than 1,500 potential omission events in the 1964-1988 period. Then, searching the Wall Street Joumal Index and Moody's Dividend Record, we positively identified 887 exact dates of omissions for our sample. 5 Typical reasons for excluding potential omission events from our sample are listed below. (The numbers included after each reason below indicate an approximate number of exclusions for that reason.)

(1) Timing differences between fiscal quarterly payments and the calendar quarter search algorithm described above. It is quite common for quarterly dividend payments to be unequally spaced throughout the year (e.g., payments are usually declared and paid at a regular interval after earnings reporting times. However, fiscal fourth quarter and, hence, annual earnings reports are regularly reported later after the close of the fiscal fourth quarter than announcements and payments after the close of the previous three fiscal quarters.) In the case of these timing differences,

5 To demonstrate the comprehensive nature of our sample of omissions, our final sample (after exclusions for data availability described below) for the years 1969-1980 was 476 omission events ( 887 in the entire 25 year sample) versus 172 in the same period by Healy and Palepu (1988). Their criteria were indeed more strict, requiring ten continuous years of dividend payments before a chosen omission event. 
multiple payments in a contiguous calendar quarter were ascertained. (approximately 450 exclusions)

(2) Companies declaring monthly dividends, and closed-end funds were excluded. (100)

(3) No record of an omission announcement could be found in the Wall Street Journal Index or Moody's Dividend Record, or the WSJ Index made it clear that no dividend omission had occurred during the suspicious time period. (40)

(4) Payment of a cash dividend was not actually omitted but changed to another type of cash payout such as a return of capital. (20)

(5) The company pre-announced the likelihood of omission within one month of the official announcement date. (10)

This procedure resulted in a sample of 887 cash dividend omission events widely spaced over the 25-year period (Table 1, Panel A). Although the number of omissions shows a negative correlation with the value of yearly changes in corporate profits ( $p=$ $-.74)$ and the one-year-lagged NYSE Index $(\rho=-.43)$, the size and length of our sample prevent any year or economic cycle from dominating our inquiry. The market capitalization and price distribution of the omission sample is quite similar to the initiation sample: over $65 \%$ of the omitting firms are in the top eight size deciles (second row, Panel B), and over $82 \%$ traded in a price range greater than five dollars, (second row, Panel C).

In order to compare the results we obtain for initiations and omissions with the post-earnings announcement drift literature, and to check for contemporaneous earnings announcements, we also collected earnings data for as many of the firms in the initiation and omission samples as possible. To do so, we searched the COMPUSTAT tapes for the period 1972-1988 for all the firms in our samples. We selected those firms where we could identify at least five consecutive recorded earnings announcement dates around the 
initiation or omission date. In most cases, 12 consecutive earnings dates were available.

We then collected all available eamings. A total of 235 initiation and 290 omission firms were able to be matched, or $36 \%$ of our sample. ${ }^{6}$ When the selection requirement was only the positive identification of the earnings date at or immediately prior to the omission event we could identify 379 omitting firms. The latter subsample will be used to ensure that the reaction to the omission announcement is not due to an announcement of contemporaneous negative earnings.

\section{Methodology: Excess Retum Calculations}

To evaluate the performance of the firms in our initiation and omission samples before, during, and after the events (initiation or omission), we calculate the returns from a buy-and-hold strategy. ${ }^{7}$ Those returns are compared to three benchmark portfolio returns. More precisely, for each stock, the excess return is defined as the geometrically compounded (buy-and-hold) return on the stock (for whatever period) minus the geometrically compounded return on either (1) the equal-weighted CRSP index including dividends, ${ }^{8}$ (2) a matching firm closest in market capitalization, or (3) a matching firm in the same industry (two-digit SIC code) which is closest in market capitalization,:

$$
E R_{j(a t o b)}=\prod_{t=a}^{b}\left(1+R_{j t}\right)-\prod_{t=a}^{b}\left(1+M R_{j t}\right)
$$

where

$\left.E R_{j(a ~ t o ~}^{b}\right)=$ Excess return for firm $j$ from time period a to $b$. For the three-day event period, the time period ( $a$ to $b$ ) is trading days $t=-1,0,+1$. For the monthly periods

6 There are several reasons for our failure to find COMPUSTAT data for our entire sample. The two most important are: (1) earnings report dates were not available on of the COMPUSTAT tapes before 1972 (our samples includes observations starting in 1964); and (2) COMPUSTAT data are sparse for smaller companies.

7 Our methodology has been strongly influenced by Ritter (1991) and Loughran and Ritter (1994).

8 Whenever we calculate excess returns for a time period greater than one month we use the equal weighted index from the CRSP monthly retum tapes to minimize the bias from compounding equally weighted daily returns (see Blume and Stambaugh, 1983). For the partial months at the beginning and end of the period we use the daily returns. 
before or after the event, the returns are calculated assuming 21 trading days for each month. That is, the 12 -month return is actually a 252 -trading-day ( 12 times 21 days) return.

$$
\begin{aligned}
& R_{j t}=\text { raw return for observation firm } j \text { on day } t . \\
& M R_{j t} \text { = return on the matching firm or the EW index on day } t .
\end{aligned}
$$

The average excess returns for each period are then:

$$
\overline{\mathrm{ER}}=\frac{1}{\mathrm{~N}} \sum_{\mathrm{j}=1}^{\mathrm{N}} \mathrm{ER}_{\mathrm{j}}
$$

T-statistics are calculated using the cross-sectional variance of excess returns as in Korajczyk, Lucas, and McDonald (1991). Tables 2 and 4 present the buy-and-hold returns. For clarity and ease of exposition, the paper initially reports the CRSP equalweighted excess returns as the benchmark. We focus on this benchmark because it is the least noisy and most easily replicable one for other researchers. Use of this benchmark also makes our results easier to compare with other research. However, we also report some results with size and industry-matched portfolio returns in Section IV, when we examine the robustness of our findings.

\section{Short-run Reactions to Omissions and Initiations}

We first compute excess returns for the firms in both samples, for the time period before the event, and for the three-day window around the event (from the day before the announcement to the day after). These excess returns are presented in Table 2. Not surprisingly, the average performance of the stocks that initiate dividends is significantly better than the benchmark porffolios in the year prior to initiation. The portfolio excess retum in that year is $15.1 \%$. During the three-day announcement (event) period, the initiation portfolios experience a significant additional excess return of $3.4 \%$ ( $t=11.08)$. These returns are observed even though the average magnitude of the annual dividend is a relatively modest $0.9 \%$ yield. (The initial yield is annualized by extrapolating from the 
first payment and is calculated using the price on the day before the dividend initiation announcement).

Firms omitting dividends perform quite poorly in the year before the omission declaration, consistent with the evidence presented in DeAngelo, DeAngelo, and Skinner (1992). The average excess return is $-31.8 \%$. As with the initiation sample, the reaction to the omission announcement is in the same direction as the price movement in the period before the announcement: omitting firms experience an additional excess return of $-7.0 \%$ in the three days around the announcement. This highly significant drop in price is a response to a major change in dividend policy. The average yield prior to the omission announcement was an annualized $6.7 \%$, much larger than the average yield at initiation.

\section{A. Are Omissions or Initiations More "Informative"?}

The more pronounced price reaction to omissions than to initiations is not unique to our sample. Healy and Palepu (1988) for example, find a $3.9 \%$ increase for a sample of 131 initiations and a $9.5 \%$ decrease for a sample of 172 omissions. In fact, this differential holds for simple dividend increases and decreases as well. Aharony and Swary (1980), for instance, find that dividend decreases are associated with a price drop of about $3.5 \%$ while dividend increases are associated with a price increase of about $1 \%$.

If dividend changes convey information about the future prospects of the firm [as postulated by Bhattacharya (1979) and Miller and Rock (1985)], then the differential response to omissions and initiations might suggest that negative changes have more information content (perhaps because they are more unusual). Bhattacharya's and Myers and Majluf (1984) results also suggest that for an equivalent dividend change, the price impact of a dividend decrease should be greater than the impact of a dividend increase (since the cost of making up a deficit in cash flow is greater than the cost of having a surplus). However, if dividend changes have information content, then presumably the information transmitted is related to the size of the change in the dividend. Initiating or omitting a $5 \%$ dividend should be more informative than initiating or omitting a dividend 
paying a $1 \%$ yield. If we assume that information content is proportional to the magnitude of the change, then the conclusion that omissions are more informative than initiations is reversed. The average change in yield at initiation is only $0.9 \%$ while the change in yield at omission is $6.7 \%$. Thus, while the price change upon the announcement of an omission is twice the change for an omission, this change is in response to an event 7 times larger. Perhaps it is initiations that are more informative!

To investigate this issue more rigorously, we use a series of OLS regressions of the three-day excess returns on the change in yield. 9 We do so using two measures of the change in yield: in the first, the last dividend paid is annualized and divided by the stock price on the day before the announcement, and, in the second, the annualized dividend on the day before the announcement is divided by the price one year before the announcement. The use of the current price needs no justification. The argument for the older price is that prices have changed over the year since the level of the dividend was set (an average drop of $31 \%$ for the omission sample), and so the current yield somewhat overstates the 'intended' yield. We also add dummy variables to test whether the effect is symmetric between initiations and omissions:

$$
E R_{i} \cdot M_{i}=\alpha_{0}+\alpha_{1} Q_{i}+\alpha_{2}\left(\frac{D}{P}\right)_{i} \cdot M_{i}+\alpha_{3} Q_{i}\left(\frac{D}{P}\right)_{i} \cdot M_{i}+\varepsilon_{i} \text { for } \mathrm{i}=1 \text { to } \mathrm{N}
$$

where

$E R_{i}$ is the three-day excess retum for security $i$, $M_{i}=-1$ if the observation is an omission or $=1$ if the observation is an initiation, $Q_{i}=1$ if omission and 0 if initiation, $\left(\frac{\mathrm{D}}{\mathrm{P}}\right)_{\mathrm{i}}$ is the ratio of the annualized dividend to the price.

The results are reported in Table 3. When we use the previous day's price to scale the change in dividend yield (first row) we find that both the slope and intercepts

9 Asquith and Mullins (1983) examines whether the larger price reaction to dividend initiations relative to regular dividend increases is because of larger change in yield. They conclude that even after accounting for the yield differences, initiations convey more information. 
differ between the initiation and omission samples. The intercept dummy is positive and the slope dummy is negative, both significant at the $1 \%$ level. This result suggests that the omission announcement per se is a more dramatic event than an initiation, but that the effect of a unit change in yield has a larger effect on prices for initiations than for omissions. Using an F-test, we can reject the hypothesis that the slope and intercept are equal for omissions and initiations at the $0.01 \%$ level. However, if the year-old price is used to define the change in yield (second row of Table 3), the differences between the slopes and intercepts for initiations and omissions are statistically insignificant. Likewise, we cannot reject the joint hypothesis that the intercept and slopes are equal for omissions and initiations using an F-test.

To see whether either of these results might be due to outliers in the sample, we have also run the same regressions using grouped data. To do so, we divided both samples into ten groups ranked by change in yield and re-examined the relationship between excess retum and yield using the means for these deciles. The results are shown in the third and fourth rows of Table 3. Regardless of whether we divide the annualized dividend by previous day price (third row) or prior year price (fourth row), neither the intercept dummy nor the slope dummy are significantly different from zero. Similarly, the F statistics also indicate that the intercept and the slope are equal for omissions and initiations (p-values of 0.346 and 0.619 using the two yield definitions respectively). Overall, the results show that when the "stale" price is used in the definition of yield, there is no asymmetry between the market reactions to initiation and omission announcements.

\section{B. Contemporaneous Events and Omission Announcements}

The pronounced market reaction to dividend omissions might be attributable to other concurrent events. To investigate this possibility, we searched the COMPUSTAT file for eamings announcements in the three-day window around the omission announcement date, and the Wall Street Journal Index for other concurrent events. The 
only events occurring in more than $5 \%$ of the omission sample were announcements of a stock dividend in lieu of the (omitted) cash dividend, and earnings announcements. $10 \mathrm{We}$ therefore investigate these two subsamples separately.

About $10 \%$ of the omitting firms (92 of the 887 ) replace the cash dividend with a stock dividend. Table 2 shows how these firms do, relative to those eliminating all payments. These firms have somewhat better performance in the year before the omission, with excess returns of $-21.9 \%$ (compared to $-33.0 \%$ for those eliminating all payouts), and the price reaction to the switch from a cash to a stock dividend at the announcement is only $-3.1 \%$, (vs. $-7.4 \%$, a significant difference). This latter result is consistent with the view that the market perceives stock dividends as a positive signal of firm quality (e.g., Brennan and Copeland (1988)). However, as we discuss below, the long-term performance for these firms is even worse than for those firms which did not substitute stock for cash dividends.

To investigate the influence of concurrent earnings announcements, we use our subsample of 379 stocks that were successfully matched with COMPUSTAT. Ninetythree of the 379 companies made an earnings announcement in one of the three days around the dividend omission announcement. For these 93 companies, the mean excess return in the three-day event window (omission announcement and eamings announcement) is $-8.0 \%$, whereas the mean for companies without an eamings announcement was $-5.6 \%$ (See Table 2, Panel C). Each of these excess returns is significantly different from zero, and the t-test comparing these two means indicates that the means are statistically different. Clearly, there is some incremental (negative) information content in the earnings release, although, as we discuss in Section 3, the long-run performance of the two groups is practically identical.

10 Other typical news events reported were corporate restructurings, takeover announcements, liquidations, and bankruptcies. The number of these concurring events was very small (less than $5 \%$ of total observations). 


\section{IIL Long-run Price Reactions}

Table 4 and Figure 1 display the performance of the initiations and omissions for up to three years after the dividend event. As before, the benchmark portfolio is the equal-weighted market index. For initiating firms, the stock prices continue to rise even after the initiation announcement: the first year excess return is $7.5 \%$, significantly different from zero $(t=3.37)$. The initiations portfolio performance continues at the same pace in the following two years. The three-year excess return is $+24.8 \%(t=3.81) .^{11}$

The omission portfolio excess returns continue to be negative long after the actual announcement. The first year excess retum is $-11 \%$, measured from the second day after the announcement, and is $-15.3 \%$ after three years. Both excess returns are significant with t-statistics of 6.33 and 4.15 respectively. ${ }^{12}$

We also examine the long-run performance of the firms with and without concurrent eamings announcements at the time of the omission announcement (see Table 4 , Panel C). The price behavior of the two subsamples is quite similar to the entire sample: a price drop of $11.9 \%$ and $12.9 \%$ after one year, and $18.2 \%$ and $19.7 \%$ after three years. We cannot reject the hypotheses that the return behavior of the two groups is identical in each of those time intervals.

The drift, however, is even more pronounced for the subsample of firms that replace the cash dividend with a stock dividend. Recall that the three day return for these firms was smaller than for the firms that omit all payouts $(-3.1 \%$ vs. $-7.4 \%)$. This difference is more than offset over the following three years. As Table 4, Panel B shows, the three-year buy-and-hold excess returns are $-31.3 \%$ versus $-13.5 \%$. (A test of these returns being different produces a t-statistic of 1.77.) This combination of a smaller initial reaction followed by a much larger drift is indeed curious.

11 When the size-matched or the industry-matched portfolios are used as the benchmark portfolios, the initiating stocks' portfolio performance is still positive after 36 months, but the excess return is no longer significant. We discuss this issue further in Section IV.

12 The price drift is $-24.2 \%$ after three years when the size-matched portfolio is used. 
The difference between the stock-dividend-paying firms and the others, interesting as it may be, is not the major story here. Of greater interest are the excess returns following initiations and omissions, excess returns that are both economically and statistically significant, and persist for a year or more. The negative excess returns following omissions is particularly surprising since we began our investigation believing that subsequent positive excess returns (consistent with overreaction) were as likely as drift. ${ }^{13}$ This raises questions regarding the comparability of our omission sample with those of De Bondt and Thaler (who find price reversals) as well as Bernard and Thomas (who find drift).

Are the negative excess returns experienced by the omission firms comparable to those of De Bondt and Thaler's "losers"? To examine this we computed the excess returns for the four year period prior to the announcement. We found that the excess returns over this period were $-45.6 \%$. For the sake of comparison, consider the excess returns of the first and second quintile of stocks (ranked on the basis of four year monthly cumulative average market-adjusted returns) reported in De Bondt and Thaler (1987). They found that the first quintile (the big losers) had four year excess returns of $-81 \%$, while the second quintile had excess returns of $-32 \%$. Our sample of omission firms falls between these two levels, but this negative performance is severe enough to expect mean reversion based on De Bondt and Thaler's results of positive excess returns over the next four years for both quintiles (25\% for the first quintile and $12 \%$ for the second quintile). Thus, while the omission firms are not the most extreme losers, their stock prices have lost enough to make one think that a price reversal is likely.

There is another interesting comparison the can be made between our initiation sample and De Bondt and Thaler's losers. De Bondt and Thaler found that the excess retums to their losers occurred primarily in January. In light of this, we have computed

13 There is less contrast between the positive drift for our initiation sample and the negative returns to De Bondt and Thaler's winners, since the latter were small and not significant. 
monthly excess returns for the omission sample in the twelve calendar months following the month of the omission event. We find that the omission portfolio actually does very well in January. The mean return for this month is $+4.6 \%$. (Part of this excess return is attributable to the small size of the omission sample, but compared to the size-matched porffolio the omission portfolio still eams a $3.1 \%$ excess return in January.) The negative excess returns occur in the other months, particularly in the fourth quarter. ${ }^{14}$

While our results are inconsistent with overreaction, are they consistent with post earnings announcement drift. Have we simply rediscovered this phenomenon? We have already shown that (for the subsample of omitting firms for which we have eamings data) only one quarter of the firms omitting a dividend actually made concurrent earnings announcements, and that the concurrence of the two announcements seems to have little effect on the long-term drift. However, even if firms do not announce earnings at the same time as the dividend omission, they might still have negative earnings surprises in surrounding quarters. To investigate this, we calculated eamings surprises in the year before and after the event for all the firms where we have sufficient data. The earnings surprise is defined as the difference between this quarter's eamings ( $E_{\mathcal{J}}$ ) and the earnings four quarters earlier, $\left(E_{\mathfrak{l}-4}\right)$ scaled by price at the end of quarter $t-4$ which is prior to the $\left(E_{1-4}\right)$ announcement (Bernard and Thomas, 1990). The earnings numbers we use are "eamings before extraordinary items" as reported by COMPUSTAT. We also calculated excess returns for the three days surrounding each eamings announcement.

The results are shown in Table 5. As expected, initiating firms have experienced positive earnings surprises and excess returns for the earnings announcements preceding the dividend initiation, and omitting firms have negative eamings surprises and excess returns before the omission announcement. What about the subsequent earnings announcements? After an earnings surprise Bernard and Thomas find significant excess

14 There is no strong seasonal pattern in the excess returns to the initiation sample. The January excess retum is $0.6 \%$ using the equal weighted index as a benchmark and $-1.5 \%$ on a size adjusted basis. Neither are significantly different from zero. 
retums (in the same direction) for three quarters, and then a significant excess return in the opposite direction one year after the event. Do our firms show the same pattern? Unfortunately, with our small sample size (compared to the thousands of events studied by Bernard and Thomas) it is not possible to say anything definitive. We do see excess returns of $1.3 \%$ and $0.9 \%$ in the two quarters after an initiation (the first of which is significant) and a significant $-1.1 \%$ excess return in the quarter following an omission. However, no other excess returns are significantly different from zero.

Another comparison with Bernard and Thomas is possible. They find that the magnitude of the drift is highly correlated with the size of the initial earnings surprise. To see whether our drift displays a similar pattern we have divided both our samples into thirds based on the change in dividend yield (the dividend surprise) at the time of the announcement. We then calculate the excess returns for the year before and three years after the event. These results are shown in Table 6. Unlike Bernard and Thomas, we find no clear relationship between the size of the "dividend surprise" and the subsequent drift. The excess returns in the year following the event are actually greatest (in absolute value) in the middle group for both omissions and initiations. For the omissions, the three year drift is, if anything, inversely related to the size of the yield change.

\section{Robustness}

There are several possible concerns one might have about the results presented so far. First, are the long-run excess returns sensitive to the particular benchmark selected? Second, could the excess returns be attributable to changes in risk? Third, are the excess returns concentrated in particular industries or years? Fourth, do the excess returns imply a viable trading rule? This section examines these concerns. 


\section{A. The benchmark portfolio}

We argued earlier that the equal weighted index is an appropriate benchmark to use in computing excess returns for our samples. However, both samples have somewhat higher concentrations of small firms that the NYSE/AMEX population (as shown in Table 1, the median firm in both samples lie in the 4 th decile) so it is possible that our results could be influenced by the size effect. To test for this possibility we recalculated excess returns using size matched porfolios. To do this, we matched each firm in both samples to the firm closest in size that did not experience an initiation or omission announcement in the year of the observation's initiation or omission. Size is measured as the market value of equity at the beginning of the event year. If the size matched firm was delisted, the returns from the equally-weighted market index were substituted. As would be expected, the resulting match is very close. The average market value of the original samples and the matched samples are practically the same (the t-statistic of the difference is 0.03 ).

Another possible worry is that our samples may be concentrated in particular industries, and a few select industries are producing the excess returns. To check out this possibility, we also constructed industry-size matched portfolios. Using similar procedures, for each firm in our samples we selected the (non-event) firm from the same two digit SIC code that was closest in size at the beginning of the year.

The results are described in Table 7. For the most part, the results are qualitatively the same as those obtained using the equal-weighted index. In both samples, the returns prior to the event, and those in the event window are very close to those shown before, with the differences being in the expected direction. (Since both samples are smaller than average, size matching involves higher benchmark returns, so positive excess returns should be smaller and negative excess returns should be more negative.) For the omission sample the post-event excess returns are more pronounced: The one year excess returns are $-13.2 \%$ for the size matched portfolio and $-14.7 \%$ for the industry 
matched, compared to $-11.0 \%$ using the equal weighted index. The three year returns are $-24.2 \%,-19.7 \%$ and $-15.3 \%$ respectively. For initiations, the positive excess returns become smaller, especially the three year returns. In fact, the three year excess returns are no longer statistically significant. Of course, the matched portfolio methodology introduces additional noise into the excess return calculations, so we put the most weight on the market adjusted returns using the equal weighted index.

In Table 7 we also report median excess returns using the equal weighted index. Although medians are not very interesting from an investment perspective, they can tell us to what extent the portfolio returns are produced by outliers. Since individual firm returns are typically right skewed (negative returns are bounded at $-100 \%$ ), median returns are usually lower than mean returns (especially for long-term returns) and our results are no exception. Thus, the median excess returns for the omissions are more negative whereas the median excess returns for the initiations are closer to zero.

Overall it is safe to conclude that neither size nor industry effects can explain the negative price drift we observe after omissions. The drift after initiations is less robust. These findings are reinforced by examining the medians.

\section{B. Risk changes}

Can the excess returns after initiation and omission announcements be explained by changes in systematic risk as measured by beta? While such an explanation is always possible, it seems unlikely in this case because of the direction of the drifts that we observe. After initiations prices drift up while after omissions they drift down, so a risk change hypothesis would have to argue that firms become riskier after initiations and less risky after omissions. It is worth noting that such a risk shift is precisely the opposite pattern of the risk changes that some authors [e.g., Chan (1988) and Ball and Kothari (1989)] have proposed as an explanation of De Bondt and Thaler's findings. Nevertheless, for completeness we have investigated this issue by taking the CRSP estimated beta of each stock in our samples for the calendar year of the event and the 
years before and after. These betas are calculated using the daily returns in that year. For the omissions, the three betas are, in order, 1.06, 0.95, and 1.08. For the initiations the three betas are: $1.34,1.35$, and 1.24. If we simply compare the pre-announcement year betas with the post announcement year betas we find that both samples show movement in the wrong direction to support a risk explanation.

Of course, beta may not be the best measure of risk. Fama and French (1993) have argued that returns are best explained by size and the ratio of market value to book value. We have reported size-adjusted returns but not returns correcting for price to book. However, it is clear what direction this correction would take. The initiation sample will tend to be high price to book (i.e., growth stocks) and the omission sample will tend to be low price to book (i.e., value stocks). Therefore, the drifts we observe will become more pronounced if we compare the returns to other stocks with these characteristics.

\section{Clustering}

While Table 1 (Panel A) indicates that neither the initiations nor the omissions events are clustered in one particular time period, it is still possible that the excess returns are dominated by one particular time period. Perhaps the drift existed in the 60 s, was recognized, and has since disappeared. We investigate this possibility by splitting our samples into two time periods so that there are equal numbers of observation in each subperiod. (The split occurs in 1975 for the initiation sample and 1976 for the omissions.) We then evaluate the porfolio performance (relative to the equally weighted index) before, during, and after the events for each subperiod. The results are reported in Table 8.

In general, we find that excess returns, before and after the announcements, are more pronounced in the second sub-period than the first. For the initiation sample, the average excess returns in the year before the event is $8.6 \%$ for the $1966-75$ period compared with $21.6 \%$ for the $1975-88$. The excess return in the three years after the 
event is $11.1 \%$ in the first sub-period and is $38.4 \%$ in the second. Similarly, the postomission announcement (days +2 to +756 ) drift is $-6.8 \%$ and $-23.9 \%$ for the first and second sub-periods respectively. A comparable picture emerges when we compare the performance in each time period to the size or industry-matched portfolios.

\section{Returns to a Trading Rule}

As a final test of the robustness of the results, we have calculated the returns to a simple trading rule. For each initiation event in our sample we buy a given long position (say $\$ 1,000$ ) in the stock at the closing price on the day after the initiation announcement and we take an equivalent short position in the equal weighted CRSP index. We hold both positions for one year (actually 252 trading days). Similarly, for every omission event we sell the stock shor at the closing price the day after the announcement and offset this with a long position in the equal weighted index. Again these positions are held for a year.

Of course, in the absence of short sale restrictions, these would be zero investment portfolios since the long positions are financed by the short sales. This makes it difficult to compute a rate of return! In light of this, we compute returns relative to the investment in the long positions only. That is, the return is the net profit (or loss) on both transactions divided by the investment in the long position. This is equivalent to assuming that the investor would be unable to get any of the proceeds of the short sale, a very conservative assumption for institutional investors. 15

In order to see how this strategy performs on a year by year basis we have assigned the profits to any given event to the year in which the event occurred, in other words, the year in which the trades were initiated. The results are shown in Figure 2. The average return across all the years is $9.7 \%$ (with a beta of 0.16 ). The returns are positive in 22 out of the 25 years, and there is only one really bad year for the strategy,

15 Individual investors typically do not get any of the proceeds of their short sale, but large institutional investors can get up to $75 \%$. 
1966. While we have not included transactions costs in our analysis, leaving out the returns to the short sale offsets this for institutional investors. We conclude from this exercise that the excess returns from this anomaly are not produced by any one time period, and appear to be economically significant.

\section{Clientele Effects}

Common Wall Street wisdom has it that stocks differ in their clienteles. For example, it is well known that institutions primarily hold stocks in large firms, and small furms are held primarily by individuals. Firms with different dividend policies are also thought to have different clienteles for two distinct reasons, one economic and one psychological. First, if dividends are taxed at a higher rate than capital gains, then high yield firms should be relatively more attractive to stockholders with low (or zero) marginal tax rates. Second, as Shefrin and Statman (1984) have argued, some individuals may prefer to own stock in dividend paying companies because they employ the rule "spend the dividends, don't touch the principal" as a self-control device. Utilities, for example, are held primarily by individuals, though they pay high dividends (see Lee, Shleifer, Thaler, 1991). Of course, if stockholders do sort themselves out according to their preferences toward cash dividends vs. capital gains, then the announcement of a dividend omission or initiation should produce a significant shift in clientele. At the time of the omission, the average firm in our sample was paying out an annual yield of $6.7 \%$, so the change in yield is substantial. For this reason, omissions are a particularly interesting case to look at for evidence of clientele shifts. (Initiations, with their much smaller $0.9 \%$ average yield, would presumably create a smaller clientele shift.) The fact that we also find long-term price drifts after dividend initiations and omissions suggests another reason to check for clientele shifts, since price pressure effects might be a plausible explanation for the drifts. With this motivation, we examine clientele effects in 
two ways, first by monitoring volume, and second by checking for shifts in institutional ownership.

One way of looking for evidence of a clientele shift is to see whether the turnover rate for firms that initiate or omit dividends shows a marked change following the announcement. To examine this we measured the trading volume for each firm in our sample for the 125 trading days ( 6 months) before the event day and for the 250 days after the event. Normal volume was defined as the portfolio's average turnover in days -125 to -5 where day zero is the event day. We then computed the portfolio's abnormal volume, $A V_{t}$, (defined as the ratio of daily turnover to normal turnover) and its standard deviation as follows:

For each stock we calculate the daily turnover $\mathrm{TO}_{\mathrm{il}}$, defined as the number of shares traded over the number of shares outstanding.

$$
\mathrm{TO}_{\mathrm{it}}=\frac{\text { Number of shares traded }_{\text {it }}}{\text { Number shares outstanding }_{\mathrm{it}}} \quad \begin{array}{ll}
\mathrm{i} & =1 \ldots \mathrm{N} \\
\mathrm{t} & =-125 \ldots 250
\end{array}
$$

where $N$ is the number of firms in the sample.

Next, the average tumover for each event is calculated using the daily turnover in days -125 to -6 :

$$
\overline{\mathrm{TO}_{\mathrm{i}}}=\sum_{\mathrm{t}=-125}^{-6} \mathrm{TO}_{\mathrm{it}} / 120
$$

Then, the portfolio daily turnover for day $t$ is defined as the simple average turnover for all securities in the sample (either initiations or omissions).

$$
\mathrm{TO}_{\mathrm{t}}=\frac{1}{\mathrm{~N}} \sum_{\mathrm{i}=1}^{\mathrm{N}} \frac{\mathrm{TO}_{\mathrm{it}}}{\overline{\mathrm{TO}}_{\mathrm{i}}} \quad \mathrm{t}=-125 \ldots 250
$$


Finally, the abnormal volume (in percentage terms) for day $t$ is defined as

$$
A V_{1}=\mathrm{TO}_{\mathrm{t}}-1 \quad \mathrm{t}=-125 \ldots 250
$$

and its standard deviation is:

S.D. $\left(A V_{t}\right)=\frac{1}{(119)} \sum_{t=-125}^{-6}\left(A V_{t}-\overline{A V}\right)^{2}$

where

$$
\overline{A V}=\frac{\sum_{t=-125}^{-6} A V_{t}}{120}
$$

The results are displayed in Table 9 and Figures $3 \mathrm{~A}$ (initiations) and 3B (omissions). The average daily turnover for the omission and initiation portfolios is $0.223 \%$ and $0.233 \%$ respectively, implying an annual turnover of $56 \%$, somewhat lower than the average NYSE daily tumover. The results for the initiation sample show that in the eleven days around the initiation announcement, abnormal volume is positive, and significantly positive in days -3 to +3 . However, the increase in tumover is not very large. The average cumulative turnover in those eleven days is only $3.23 \%$ compared with the normal eleven day turnover of $2.56 \%$. Also, as Figure $3 \mathrm{~A}$ shows, there is no appreciable increase in tumover in the subsequent year.

Firms that omit dividends show a similar pattern shown in the second column of Table 9. Significantly positive abnormal volume is detected up to nine days after the omission date, but the cumulative average turnover in the eleven days around the announcement is $3.62 \%$, compared with a normal eleven day turnover of $2.45 \%$. Once again, there is no discernible change in volume in the year following the omission announcement. 
The relatively minor increase in volume during the event window, and the absence of an increase thereafter, strongly suggests that if there are changes in clientele going on, they are not very dramatic. ${ }^{16}$ Of course, changes in clientele could occur (albeit gradually) without an increase in volume. We have, therefore, also undertaken a direct investigation of whether the share of institutional ownership changes after a dividend omission. ${ }^{17}$ To do this we used the Standard and Poor's Stock Guide to obtain an estimate of the percentage of shares held by institutions for the three years before and three years after the omission announcement. The data on institutional holdings began to appear in the stock guide in 1979 , so we are able to obtain three years of prior data only for omissions occurring in 1982 and later. For this reason, and because not every firm is listed in the Stock Guide, our sample of omitting firms falls from 887 to $168 .{ }^{18}$ For these 168 firms, we then computed the average institutional ownership share for the three years preceding the event and the three years after the event. Averaging across all firms, we find that the mean institutional holdings before the omission announcement are $30.0 \%$ (18.1\% standard deviation) while the mean post event share is $30.9 \%$ (17.6\%). The insignificant change in institutional holdings combined with the small increase in volume during the omission period and no increase thereafter indicates that there are no significant clientele changes associated with dividend initiations and omissions.

16 In investigating volume and price changes of 192 firms that initiated dividends, Richardson, Sefcik, and Thompson (1986) conclude that the volume increase is primarily in response to the news contained in the initiation announcement.

17 We also tried to collect data on instibutional ownership for initiating firms but could not obtain a large enough sample size to make an analysis possible. The problem is that many initiating firms are too small to be included in the S \& P Stock Guide, the source of our ownership data.

18 We also deleted firms when the year to year changes were so wild as to suggest that one of the observations was an error. For example, if the institutional holdings for three consecutive years were recorded as $20,2,23$, we suspected that the middle year was an error and dropped the observation. 


\section{Summary and Conclusion}

We have six principal findings.

1. The short run price impact of a dividend omission is greater than for a dividend initiation. This effect is partly due to the much larger change in yield associated with omissions.

2. There are significant excess returns in the years after the announcement of dividend initiations and omissions.

3. Firms that replace a cash dividend with a stock dividend experience a smaller immediate price drop, but an even more pronounced three year negative drift.

4. The long-term drifts after initiations and omissions do not depend on whether the firm made a coincident earnings announcement, nor do they depend importantly on the magnitude of the change in yield.

5. A trading rule based on the one year drifts earns positive returns in 22 out of 25 years.

6. There is no evidence of an important clientele shift for either the initiation or omission samples.

Of these findings, the most surprising are the ones that concem the significant long-term drifts following announcements of initiations and especially omissions. These drifts are surprising on several counts. First, from an efficient market perspective predictable excess returns are always surprising. In the case of the omissions, where the drift is large and robust, our attempts to correct for risk or size only make the excess returns larger. Second, firms that omit a dividend are prior losers, not unlike those studied by De Bondt and Thaler who find significantly positive excess returns. Third, while the negative drift resembles that found by Bernard and Thomas and others who have investigated post eamings announcement drift, this does not seem to be the same phenomenon. The drift here is more pronounced, lasts longer, and does not appear to 
occur primarily around subsequent earnings announcements. Fourth, we can find no evidence of important shifts in clientele, which eliminates price pressure as a potential explanation for the anomalous drift. What then is the explanation for these surprising results? We are open to suggestions. 


\section{References}

Aharony, Joseph, and Itzhak Swary, 1980, Quarterly Dividend and Earnings

Announcements and Stockholders' Returns: An Empirical Analysis, Journal of Finance 35, 1-12.

Asquith, P. and D.W. Mullins, 1983, The Impact of Initiating Dividend Payments on Shareholder' Wealth, Journal of Business 56, 77-96.

Ball, Ray, and P. Brown, 1968, An Empirical Evaluation of Accounting Income Numbers, Journal of Accounting Research Autumn, 159-178.

Bernard, Victor L., and Jacob K. Thomas, 1989, Post-eamings-Announcement Drift: Delayed Price Response or Risk Premium?, Journal of Accounting Research 27 (S), 1-36.

Bernard, Victor L., and Jacob K. Thomas, 1990, Evidence That Stock Prices Do Not Fully Reflect the Implications of Current Earnings for Future Earnings, Journal of Accounting and Economics 13, 305-340.

Black, Fisher, and Myron Scholes, 1974, The Effects of Dividend Yield and Dividend Policy on common Stock Prices and Retums, Journal of Financial Economics 1, 1-22.

Blume, Marshall E., and Robert F. Stambaugh, 1983, Biases in Computed Returns: An Application To The Size Effect, Journal of Financial Economics 12, 387-404. Brennan, Michael and Thomas Copeland, 1988, Stock Splits, Stock Prices, and Transaction Costs, Journal of Financial Economics 22, 83-101.

Bremer, Marc and Richard J. Sweeny, 1991, The Reversal of Large Stock-Price Decteases, Journal of Finance 46, 747-754.

Brown, Stephen J., and Jerold Warner, 1985, Using Daily Stock Returns: The Case of Event Studies, Journal of Financial Economics 14, 3-31.

Charest, Guy, 1978, Dividend Information, Stock Returns and Market Efficiency - II, Journal of Financial Economics , 6, 297-330. 
Chopra, Navin, Josef Lakonishok, and Jay R. Ritter, 1992, Measuring Abnormal Performance: Do Stocks Overreact?, Journal of Financial Economics 31, 235268.

Christie, William G., 1990, Dividend Yield and Expected Retums: The Zero-Dividend Puzzle, Journal of Financial Economics , 28, 1990.

DeAngelo, Harry, Linda DeAngelo, and Douglas Skinner, 1992, Dividends and Losses, Journal of Finance, 47, 1837-1864.

De Bondt, Werner and Richard Thaler, 1987, Further Evidence On Investor Overreaction and Stock Market Seasonality, Journal of Finance 42, 557-581.

De Bondt, Werner and Richard Thaler, 1985, Does the Stock Market Overreact?, Journal of Finance 40, 793-808.

De Bondt, Werner and Richard Thaler, 1989, Anomalies: A Mean-Reverting Walk Down Wall Street, Journal of Economic Perspectives Winter, 189-202.

Fama, Eugene and Kenneth French, 1993, Common Risk Factors in the Returns of Stocks and Bonds, Journal of Financial Economics 33, 3-56.

Foster, George, 1977, Quarterly Accounting Data: Time Series Properties and Predictiveability Results, The Accounting Review January, 1-21.

Foster, George, C. Olsen, and T. Shevlin, 1984, Earnings Releases, Anomalies, and the Behavior of Security Returns, The Accounting Review 59, 574-603.

Harris, Lawrence and Eitan Gurel, 1986, Price and Volume Effects Associated with Changes in the S\&P500: New Evidence for the Existence of Price Pressures, Journal of Finance 41, 815-830.

Healy, Paul and Krishna Palepu, 1988, Earnings Information Conveyed by Dividend Initiations and Omissions, Journal of Financial Economics 21, 149-175.

Jensen, Michael, and William Meckling, 1976, Theory of the Firm: Managerial Behavior, Agency Costs and Ownership Structure, Journal of Financial Economics 3, 305360 . 
Lakonishok, Josef, Andrei Shleifer, and Vishny, 1993, Contrarian Investment, Extrapolation and Risk, Working Paper, University of Illinois.

Lee, Charles, Andrei Shleifer, and Richard Thaler, 1991, Investor Sentiment and the Closed-End Fund Puzzle, Journal of Finance 46, 75-109.

Loughran, Tim and Jay. R. Ritter, 1994 "The Timing and Subsequent Performance of New Issues," unpublished University of Illinois working paper.

Miller, Merton and Scholes, Myron, 1982, Dividends and Taxes: Some Empirical Evidence, Journal of Political Economy 90, 1118-1141.

Myers, Stewart, 1977, Determinants of Corporate Borrowing, Journal of Financial Economics 5, 147-175.

Richardson, Gordon, Stephan Sefcik, and Rex Thompson, 1986, A Test of Dividend Irrelevance Using Volume Reactions to a Change in Dividend Policy, Journal of Financial Economics 17, 313-333.

Ritter, Jay R., 1991, The Long-Run Performance of Initial Public Offerings, Journal of Finance 46, 3-28.

Scholes, Myron and Joseph T. Williams, 1977, Estimating Betas From Nonsynchronous Data, Journal of Financial Economics, 5, 309-327.

Shefrin, Hersh M. and Meir Statman, 1984, Explaining Investor Preference for Cash Dividends, Journal of Financial Economics, 13, 253-282.

Shleifer, Andrei, 1986, Do Demand Curves for Stocks Slope Down?, Journal of Finance, $41,579-590$. 
Table 1

Descriptive Statistics of Dividend Initiations and Omissions, 1964-1988 Included in the initiation sample are all NYSE/AMEX companies that traded for at least two years before the first dividend announcement, as recorded on the CRSP tapes. Foreign companies, ADRs, closed-end funds, and companies that pay monthly dividends are excluded. Firms are included in the omission sample if they are traded on the NYSE/AMEX for at least two years, skipped at least one dividend and had an identifiable omission announcement in the WSJ Index. The annual aggregate percentage change in U.S. corporate profits is gathered from the Federal Reserve publications, and the percentage change in the NYSE index is taken from the NYSE fact book.

Panel A: Distribution of Dividend Initiations and Omissions by Year, 1964-1988

\begin{tabular}{|c|c|c|c|c|c|c|}
\hline Year & Omissions & $\begin{array}{c}\text { Omissions } \\
\text { Percent of } \\
\text { Sample } \\
\end{array}$ & Initiations & $\begin{array}{c}\text { Initiations } \\
\text { Percent of } \\
\text { Sample } \\
\end{array}$ & $\begin{array}{c}\text { Percentage change } \\
\text { in U.S. corp. } \\
\text { Profits } \\
\end{array}$ & $\begin{array}{l}\text { Percentage change in } \\
\text { NYSE Index } \\
\text { (excluding dividends) }\end{array}$ \\
\hline 1964 & 12 & 1.4 & 39 & 6.9 & 12.5 & 14.4 \\
\hline 65 & 15 & 1.7 & 26 & 4.8 & 16.5 & 9.5 \\
\hline 66 & 18 & 2.0 & 17 & 3.0 & 8.2 & -12.6 \\
\hline 67 & 29 & 3.3 & 11 & 2.0 & -5.2 & 23.1 \\
\hline 68 & 22 & 2.5 & 10 & 1.8 & 9.8 & 9.4 \\
\hline 69 & 41 & 4.6 & 10 & 1.8 & -3.1 & -12.5 \\
\hline 70 & 98 & 11.0 & 8 & 1.4 & -112 & -2.5 \\
\hline 71 & 47 & 5.3 & 15 & 2.7 & 14.9 & 12.3 \\
\hline 72 & 28 & 3.2 & 31 & 5.5 & 15.8 & 14.3 \\
\hline 73 & 21 & 2.4 & 57 & 10.1 & 25.2 & -19.6 \\
\hline 74 & 58 & 6.5 & 35 & 6.2 & 8.8 & -30.3 \\
\hline 75 & 47 & 5.3 & 53 & 9.4 & -3.4 & 31.9 \\
\hline 76 & 24 & 2.7 & 77 & 13.7 & 25.9 & 21.5 \\
\hline 77 & 20 & 2.3 & 51 & 9.1 & 20.5 & -9.3 \\
\hline 78 & 18 & 2.0 & 21 & 3.7 & 16.5 & 2.1 \\
\hline 79 & 30 & 3.4 & 17 & 3.0 & 10.1 & 15.5 \\
\hline 80 & 44 & 5.0 & 14 & 2.5 & -7.8 & 25.7 \\
\hline 81 & 47 & 5.3 & 10 & 1.8 & -4.5 & -8.7 \\
\hline 82 & 74 & 8.3 & 9 & 1.6 & -25.1 & 14.0 \\
\hline 83 & 19 & 2.1 & 7 & 1.2 & 22.4 & 17.5 \\
\hline 84 & 27 & 3.0 & 6 & 1.1 & 15.6 & 1.3 \\
\hline 85 & 50 & 5.6 & 6 & 1.1 & -6.5 & 26.1 \\
\hline 86 & 52 & 5.9 & 10 & 1.8 & -12 & 14.0 \\
\hline 87 & 27 & 3.0 & 9 & 1.6 & 24.2 & -0.3 \\
\hline 88 & 12 & 2.1 & 12 & 2.1 & 15.0 & 13.0 \\
\hline Totals & 887 & 100.0 & 561 & 100.0 & & \\
\hline
\end{tabular}

Panel B: Market Capitalization Deciles

\begin{tabular}{ccccccccccc} 
Decile & 1st & 2nd & 3rd & 4th & 5th & 6th & 7th & 8th & 9th & 10h \\
\hline Initiations (\%) & 8.0 & 13.5 & 18.5 & 14.1 & 14.6 & 11.4 & 8.6 & 6.1 & 3.9 & 1.2 \\
Omissions (\%) & 14.5 & 18.0 & 15.3 & 12.1 & 12.5 & 8.7 & 9.6 & 5.2 & 2.9 & 1.1
\end{tabular}

Panel C: Stock Price Per Share of Initiating and Omitting Firms (day before the event).

\begin{tabular}{ccccccccc} 
Price (\$) & $<5$ & $5-10$ & $10-15$ & $15-20$ & $20-30$ & $30-40$ & $40-50$ & $>50$ \\
\hline Initiations (\%) & 20.1 & 30.1 & 17.8 & 11.9 & 11.2 & 4.5 & 1.6 & 2.3 \\
Omissions (\%) & 17.9 & 39.7 & 20.4 & 10.1 & 7.2 & 2.5 & 0.6 & 1.1
\end{tabular}


Table 2

\section{Market-Adjusted Returns for Periods Before and At Announcement Date for Corporations Initiating and Omitting Cash Dividends}

Market-adjusted returns for the initiation and omission samples (1964-1988) are calculated for the one year and three months prior to the three-day event period and for the event period centered around the event day. Buy and hold (market adjusted) returns are calculated as follows:

$$
E R_{j(a \text { เ } b)}=\prod_{t=a}^{b}\left(1+R_{j t}\right)-\prod_{t=a}^{b}\left(1+M R_{t}\right)
$$

where $\operatorname{ER} j(a$ to $b)=$ Excess return for firm $j$ from time period a to $b, R_{j t}=$ raw return for firm $j$ in day or month $t, M R_{t}=$ return on the CRSP NYSE/AMEX equally-weighted market index for day or month $t$. The EW market geometrically compounded return is calculated from the monthly and daily CRSP return tapes. T-statistics are calculated based on the cross sectional variance in the mean excess return in the relevant period. Dividend yield is defined as the annualized dividend over the price the day before the event. In Panel A excess returns are calculated for the entire samples of initiations (561 observations) and omissions (887 observations). In Panel B we divide the omission sample into firms that paid and did not pay a stock dividend in lieu of the cash dividend, and in Panel $C$ we compare the mean excess return of a subsample of firms that had contemporaneous earnings announcements to the ones that did not have a contemporaneous announcement.

Market-adjusted returns (T-statistics) for holding period relative to event day

\begin{tabular}{|c|c|c|c|c|c|}
\hline \multirow{2}{*}{\multicolumn{2}{|c|}{ Panel A: Entire samples }} & $\begin{array}{c}\text { From day }-254 \\
\text { to day }-2\end{array}$ & $\begin{array}{l}\text { From day }-65 \\
\text { to day }-2\end{array}$ & $\begin{array}{c}\text { From day }-1 \text { to } \\
\text { day }+1\end{array}$ & $\begin{array}{c}\text { Dividend Yield } \\
\left(x_{0}\right)\end{array}$ \\
\hline & & & & & \\
\hline Initiations & $n=561$ & $\begin{array}{l}15.1 \\
(6.4)\end{array}$ & $\begin{array}{l}4.7 \\
(5.2)\end{array}$ & $\begin{array}{c}3.4 \\
(11.08)\end{array}$ & 0.9 \\
\hline Omissions & $\mathrm{n}=887$ & $\begin{array}{l}-31.8 \\
(-31.6)\end{array}$ & $\begin{array}{l}-11.2 \\
(-18.9)\end{array}$ & $\begin{array}{c}-7.0 \\
(-24.75)\end{array}$ & 6.7 \\
\hline
\end{tabular}

Panel B: Separating the emission sample into stocks that paid and substituted and did not substitute a

\begin{tabular}{llllll}
\multicolumn{5}{c}{ stock for cash dividend } & \multicolumn{1}{c}{} \\
\hline Stock dividend in lieu & $\mathrm{n}=92$ & -21.9 & -7.5 & -3.1 & 5.5 \\
No slock dividend & $\mathrm{n}=795$ & -33.0 & -11.6 & -7.4 & 6.9 \\
T-stat of difference & & $(3.62)$ & $(2.32)$ & $(5.45)$ &
\end{tabular}

Panel C: Separating the omission sample into firms that had and did not have concurrent eamings and

\begin{tabular}{|c|c|c|c|c|}
\hline \multirow{3}{*}{$\begin{array}{l}\text { Contemporaneous } \\
\text { eamings announcement } \\
\text { Omission } \\
\text { announcement only } \\
\text { T-stat of difference }\end{array}$} & $n=93$ & -34.1 & -13.2 & -8.0 \\
\hline & $\mathrm{n}=286$ & -34.6 & -11.7 & -5.5 \\
\hline & & $(0.14)$ & $(0.79)$ & \\
\hline
\end{tabular}


Table 3

Dividend Yield Changes as A Determinant of the Price Reaction around Initiation and Omission Announcements

Using multivariate linear regression, we investigate the relationship between the market reaction to the initiation/omission announcement and the change in yield:

$$
E R_{i} \cdot M_{i}=\alpha_{0}+\alpha_{1} Q_{i}+\alpha_{2}\left(\frac{D}{P}\right)_{i} \cdot M_{i}+\alpha_{3} Q_{i}\left(\frac{D}{P}\right)_{i} \cdot M_{i}+\varepsilon_{i}, \quad i=1 \ldots N
$$

where $E R_{i}$ is the three-day excess return for security $i, M_{i}=-1$ if the observation is an omission or $=1$ if the observation is an initiation, $Q_{i}=1$ if omission and 0 if initiation, $\left(\frac{D}{P}\right.$ )$_{i}$ is the ratio of the annualized dividend to the price on the day before (first and third regressions) or the year before the announcement (second and fourth regressions). To reduce the outliers effects in the last two regressions, observations are grouped according to their yield into 10 omissions and 10 initiations deciles. The F-statistics tests the joint hypotheses that both the intercept and the slope dummies are insignificantly different from zero. T-statistics are in parentheses.

$\begin{array}{ccccccc}\text { Intercept } \alpha_{0} & \begin{array}{c}\text { Intercept } \\ \text { Dumnny } \alpha_{1}{ }^{*} Q_{i}\end{array} & \begin{array}{c}\text { Yield } \\ \text { Coefficient } \alpha_{2}\end{array} & \begin{array}{c}\text { Slope Dummy } \\ \text { Coefficient } \alpha_{3}\end{array} & \begin{array}{c}\text { F-Test } \\ \text { (probability) }\end{array} & \mathbf{R}^{2} & \mathbf{N}\end{array}$

(1) When Yield $=\mathrm{D} / \mathrm{P}_{\mathrm{t}-1}$

$\begin{array}{rrrrrrr}0.011 & 0.029 & 2.117 & -1.67 & 13.47 & 0.16 & 1448 \\ (2.43) & (4.91) & (5.59) & (-4.40) & (0.00) & & \end{array}$

(2) When Yield $=\mathrm{D} / \mathbf{P}_{\mathbf{t}-250}$

$\begin{array}{ccccccc}0.019 & 0.004 & 0.997 & 0.10 & 0.70 & 0.14 & 1448 \\ (4.52) & (0.53) & (3.88) & (0.36) & (0.50) & & \end{array}$

(3) When Yield $=D / P_{t \cdot 1}$, Grouped Data

$\begin{array}{ccccccc}0.0097 & 0.009 & 1.62 & -0.81 & 1.13 & 0.90 & 20 \\ (1.75) & (1.05) & (3.04) & (0.54) & (0.35) & & \end{array}$

(4) When Yield $=\mathrm{D} / \mathrm{P}_{\mathrm{t}-250}$, Grouped Data

$\begin{array}{ccccccc}0.010 & -0.003 & 1.16 & 0.32 & 2.01 & 0.92 & 20 \\ (2.06) & (-0.34) & (3.51) & (0.90) & (0.62) & & \end{array}$


Table 4

\section{Market-Adjusted Returns for Periods At and After Announcement Date for Corporations Initiating and Omitting Cash Dividends}

Market-adjusted retums for the initiation and omission samples (1984-1988) are calculated for the three-day event period and for the three-month, one-year, two-year, and three-year periods beginning two trading days after the event day. The methodology is the same as in Table 2. In Panel A excess returns are calculated for the entire samples of initiations ( 561 observations) and omissions ( 887 observations). In Panel B we divide the omission sample into firms that paid and did not pay a stock dividend in lieu of the cash dividend, and in Panel $C$ we compare the mean excess return of a subsample firms that had contemporaneous earnings announcements to the ones that did not have a contemporaneous announcement.

Market-adjusted returns (T-statistics) for holding period relative to event day

\begin{tabular}{|c|c|c|c|c|c|c|}
\hline Panel A: Entire sample & & $\begin{array}{c}\text { From day }-1 \\
\text { to day }+1\end{array}$ & $\begin{array}{c}\text { From day }+2 \\
\text { o day }+65\end{array}$ & $\begin{array}{l}\text { From day }+2 \\
\text { to day }+254\end{array}$ & $\begin{array}{l}\text { From day }+2 \\
\text { to day }+506\end{array}$ & $\begin{array}{l}\text { From day }-2 \\
\text { to day }+758\end{array}$ \\
\hline Initiations & $n=887$ & $\begin{array}{c}3.4 \\
(11.08)\end{array}$ & $\begin{array}{l}1.8 \\
(1.97)\end{array}$ & $\begin{array}{c}7.5 \\
(3.37)\end{array}$ & $\begin{array}{l}15.6 \\
(3.47)\end{array}$ & $\begin{array}{l}24.8 \\
(3.81)\end{array}$ \\
\hline Omiss & $n=561$ & $\begin{array}{c}-7.0 \\
(-24.75)\end{array}$ & $\begin{array}{l}-4.6 \\
(-6.34)\end{array}$ & $\begin{array}{l}-11.0 \\
(-6.33)\end{array}$ & $\begin{array}{l}-15.0 \\
(-5.88)\end{array}$ & $\begin{array}{l}-15.3 \\
(-4.15)\end{array}$ \\
\hline
\end{tabular}

Panel B: Separating the omission sample into stocks that paid and substituted and did not substitute a sock for cash dividend

\begin{tabular}{|c|c|c|c|c|c|c|}
\hline Stock dividend in lieu & $n=92$ & -3.1 & -7.6 & -15.2 & -21.9 & -31.3 \\
\hline No stock dividend & $\mathrm{n}=795$ & -7.4 & -4.3 & .10 .5 & -14.1 & -13.5 \\
\hline T-stat of difference & & $(5.45)$ & (1.74) & $(0.85)$ & $(0.94)$ & (1.77) \\
\hline
\end{tabular}

Panel C: Separating the omission sample into firms that had and did not have concurrent eamings and omission announcements (in the three-day event window)

\begin{tabular}{lcccccc}
\hline $\begin{array}{l}\text { Contemporaneous } \\
\text { camings } \\
\text { announcement }\end{array}$ & $\mathrm{n}=93$ & -8.0 & -6.0 & -11.9 & -12.0 & -18.2 \\
$\begin{array}{l}\text { Omission } \\
\text { announcement only }\end{array}$ & $\mathrm{n}=286$ & -5.5 & -5.3 & -12.9 & -19.5 & -19.7 \\
$\begin{array}{l}\text { T-stat of difference } \\
\text { and }\end{array}$ & & $(2.63)$ & $(0.34)$ & $(0.14)$ & $(0.74)$ & $(0.12)$
\end{tabular}


Table 5

Price Reactions to Earnings Announcements from One Year Before and to One Year After the Dividend Announcements

We collected available (beginning in 1972) quarterly eamings announcement dates and earnings before extraordinary items for dividend initiating and omitting firms. We calculated earnings surprises (ES) using the seasonal random walk model as in Bemand and Thomas (1990). That is: $E S_{q u t}=\frac{E B E I_{t}-E B E I_{t-4}}{P R I C E_{\text {ad qut } 14}}$ where EBEI is the earnings before extraordinary items and PRICE is the stock price at the end of the prior measurement period. Excess returns are calculated as in Tables 2 and 4 for the three-day returns centered around the eamings announcement day for each quarterly report.

Panel A: Initiations

\section{Quarter relative to} Initiation day

$$
\begin{gathered}
-4 \\
-3 \\
-2 \\
-1 \\
0 \\
1 \\
2 \\
3 \\
4
\end{gathered}
$$

NOBS
174
203
212
181
42
227
235
231
227

Panel B: Omissions

\section{Quarter \\ relative to emission day}

$\begin{array}{cc}-4 & 248 \\ -3 & 277 \\ -2 & 278 \\ -1 & 204 \\ 0 & 86 \\ 1 & 281 \\ 2 & 290 \\ 3 & 297 \\ 4 & 278\end{array}$

$\begin{array}{ccc}\begin{array}{c}\text { Mean } \\ \text { Earning } \\ \text { Surprise (\%) }\end{array} & \begin{array}{c}\text { Mean } \\ \text { Excess } \\ \text { Retum (\%) }\end{array} & \begin{array}{c}\text { T-Stat } \\ \text { of ER =0 }\end{array} \\ +2.6 & 1.6 & 2.45 \\ +2.9 & 1.0 & 1.85 \\ +2.7 & 0.9 & 1.82 \\ +2.4 & 1.0 & 1.94 \\ +2.5 & 6.0 & 4.84 \\ +2.6 & 1.3 & 2.53 \\ +1.7 & 0.9 & 1.22 \\ +1.2 & -0.2 & 0.58 \\ -0.1 & 0.0 & 0.09\end{array}$
Surprise (\%) Return (\%) T-Star

$\begin{array}{cccc}\text { NOBS } & \begin{array}{c}\text { Earning } \\ \text { Surprise (\%) }\end{array} & \begin{array}{c}\text { Excess } \\ \text { Return (\%) }\end{array} & \text { T-Stat } \\ 248 & -1.4 & -1.6 & 4.86 \\ 277 & -2.2 & -2.2 & 0.30 \\ 278 & -3.5 & -1.5 & 4.04 \\ 204 & -4.0 & -2.1 & 4.89 \\ 86 & -5.4 & -8.8 & 9.77 \\ 281 & -6.6 & -1.1 & 2.92 \\ 290 & -4.1 & 0.4 & 0.93 \\ 297 & -1.1 & 0.4 & 0.96 \\ 278 & 2.2 & 0.1 & 0.37\end{array}$

- Quarter 0 represents quarterly eamings announcements that were coincident with the initiation and omission three-day event period windows. 
Table 6

Market-Adjusted Returns for Firms Initiating and Omitting Dividends, Separated into Thirds by (Change in Yield)

We compare post-event market-adjusted retums for three equal-number-of-observation groups based on the magnitude of the yield change (surprise). The methodology is the same as in Table 2.

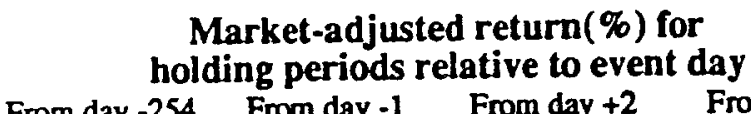

From day -254 From day $-1 \quad$ From day +2 From day +2 to day -2 to day +1 to day +254 to day +758

Panel A: Initiations

Yield change $0.0-0.5 \%$ 22.3

1.6

4.5

Yield change $0.5 \%-0.93 \%$

13.6

2.8

10.5

39.9

Yield change $0.93-8.0 \%$

9.5

5.7

7.6

19.9

Panel B: Omissions

\begin{tabular}{llllc}
\hline Yield change $0.0-3.9 \%$ & -23.7 & -4.2 & -10.0 & -17.2 \\
Yield change 3.9\%-6.9\% & -33.4 & -6.6 & -12.9 & -16.3 \\
Yield change $7.0 \%-77 \%$ & -38.4 & -10.3 & -9.8 & -12.2 \\
\hline
\end{tabular}


Table 7

Size and Industry Adjusted Returns for Corporations Initiating and Omitting Dividends

Each firm in the sample is matched to a non-event firm by size (industry). We then calculate the buy and hold size (industry) adjusted return for the initiating and omitting portfolios:

$$
E R_{j(a \leftarrow b)}=\prod_{t=a}^{b}\left(1+R_{j t}\right)-\prod_{t=a}^{b}\left(1+M R_{j t}\right)
$$

where $\operatorname{ER}_{j}(\mathrm{a}$ to $b)=$ Excess return for firm $\mathrm{j}$ from time period $\mathrm{a}$ to $\mathrm{b}, \mathrm{R}_{\mathrm{jt}}=$ raw return for firm $j$ in day or month $t, M R j t=$ return on the matching firm (by size or industry) or on CRSP NYSE-AMEX equally weighted market index (for market-adjusted means or medians) in day or month $t$. If the matching firm was delisted before the sample firm, the equally-weighted market index was substituted for the matching-firm return. T-statistics are calculated based on the cross-sectional variance of the excess returns in the relevant period.

Excess returns (t-statistics) for
holding periods relative to event day
\begin{tabular}{cccc} 
From day -254 & From day -1 & From day +2 & From day +2 \\
to day -2 & to day +1 & 10 day +254 & to day +758 \\
(1 yr. pre-event) & (event return) & (1 yr. post-event) & (3 yr. post-event) \\
\hline
\end{tabular}

Panel A: Initiations

\begin{tabular}{lcccc}
\hline Mean, size-matched portfolio & 14.3 & 3.5 & 6.0 & 8.7 \\
& $(4.53)$ & $(8.89)$ & $(2.05)$ & $(1.03)$ \\
Mean, industry-matched & 13.5 & 3.0 & 0.76 & 8.6 \\
portfolio & $(4.63)$ & $(7.40)$ & $(0.25)$ & $(1.07)$ \\
Mean, market adjusted (EW) & 15.1 & 3.4 & 7.5 & 24.8 \\
& $(6.4)$ & $(11.08)$ & $(3.37)$ & $(3.81)$ \\
Median, market adjusted (EW) & 0.6 & 2.3 & 1.7 & -1.4 \\
& & & & \\
Panel B: Omissions & & & & \\
\hline Mean, size-matched portfolio & -32.3 & -6.7 & -13.2 & -24.2 \\
& $(-18.4)$ & $(-20.34)$ & $(-5.09)$ & $(-4.94)$ \\
Mean, industry-matched & -28.1 & -7.1 & -14.7 & -19.7 \\
portfolio & $(-16.10)$ & $(-21.10)$ & $(-6.00)$ & $(4.13)$ \\
Mean, market adjusted (EW) & -31.8 & -7.0 & -11.0 & -15.3 \\
& $(-31.6)$ & $(-24.75)$ & $(-6.33)$ & $(-4.15)$ \\
Median, market adjusted (EW) & -32.5 & -6.3 & -18.1 & -32.0 \\
\hline
\end{tabular}


Table 8

Market-Adjusted Returns for Firms Initiating and Omitting Dividends When the Sample is Divided Into Two Time Periods

Market-adjusted buy and hold returns for the initiation ad omission sample (1964-1988) are calculated for the year before, the three days of, and for the one, two, and three years after the events. The methodolgy is the same as in Table 2. Each sample is divided into two time periods so that that number of events in each time period are equal.

Market-adjusted returns (\%)

for holding period relative to event day

\begin{tabular}{|c|c|c|c|c|c|c|}
\hline \multicolumn{2}{|c|}{ Panel A: Initiations } & $\begin{array}{l}\begin{array}{l}\text { From day }-254 \\
\text { to day }-2\end{array} \\
\end{array}$ & $\begin{array}{l}\text { From day }-1 \\
\text { Lo day }+1\end{array}$ & $\begin{array}{l}\text { From day }+2 \\
\text { to day }+254\end{array}$ & $\begin{array}{l}\text { From day }+2 \\
\text { L day }+506 \\
\end{array}$ & $\begin{array}{l}\text { From day }-2 \\
\text { w day }+758 \\
\end{array}$ \\
\hline $1966-1975$ & $n=443$ & 8.6 & 3.1 & 1.7 & 2.7 & 11.1 \\
\hline $1975-1988$ & $n=444$ & 21.6 & 3.7 & 13.3 & 28.3 & 38.4 \\
\hline \multicolumn{7}{|c|}{ Panel B: Omissions } \\
\hline $1966-1976$ & $\mathrm{n}=280$ & -27.6 & -8.0 & -7.5 & -8.9 & -6.8 \\
\hline $1976-1988$ & $n=281$ & -36.0 & -6.0 & -14.6 & -21.1 & -23.9 \\
\hline
\end{tabular}


Table 9

\title{
Abnormal Trading Volume Around Dividend Initiation and Omission Announcements
}

\begin{abstract}
Abnormal volume is calculated in the twenty days centered around the initiation/omission announcement. Normal volume is defined as the average daily turnover in day -125 to -5 relative to the event, and abnormal volume is the daily turnover in the event day minus the average daily tumover, relative to the daily average turnover. Turnover's standard deviation is calculated in the estimation period (day -125 to day -5 ) from the average daily turnover.
\end{abstract}

(1)

Dividend Initiations

Day Relative to Announcement Date
Abnormal Volume (\%)
(2)

Dividend Omissions

Abnormal Volume (\%)

T-Stat

$\begin{array}{ll}-0.4 & -0.07 \\ -0.4 & -0.07\end{array}$

$3.8 \quad 0.61$

$\begin{array}{ll}-4.1 & -0.65\end{array}$

$-5.8 \quad-0.94$

$-6.6 \quad-1.06$

$1.7 \quad 0.28$

$8.6 \quad 1.39$

$4.6 \quad 0.74$

$126.1 \quad 20.31$

$191.0 \quad 30.77$

$98.8 \quad 15.92$

$55.2 \quad 8.90$

$42.8 \quad 6.89$

$26.6 \quad 4.28$

$30.0 \quad 4.84$

$38.8 \quad 6.25$

$12.9 \quad 2.07$

$11.2 \quad 1.80$

$15.9 \quad 2.56$

$\begin{array}{rr}5.9 & 2.56 \\ 0.0 & -0.01\end{array}$

3.3

0.9

0.52

0.14 


\section{Figure 1}

Buy and Hold Adjusted Returns for Corporations Initiating and Omitting Cash

Dividends in the Period 1964-1988:

Buy and hold adjusted returns for the initiation and omission samples are calculated from the one year before to the third year after the event month. The market-adjusted benchmark compares the security return to the equal weighted index return. Buy and hold returns are calculated as follows: $E R_{j(a \text { w } b)}=\prod_{t=a}^{b}\left(1+R_{j t}\right)-\prod_{t=a}^{b}\left(1+M R_{j t}\right)$ where $E R_{j}(a$ to $b)=$ Excess return for firm $j$ from time period $a$ to $b, R_{j t}=$ raw return for firm $j$ for month $t, M R_{j t}=$ return on the EW index for month $t$.

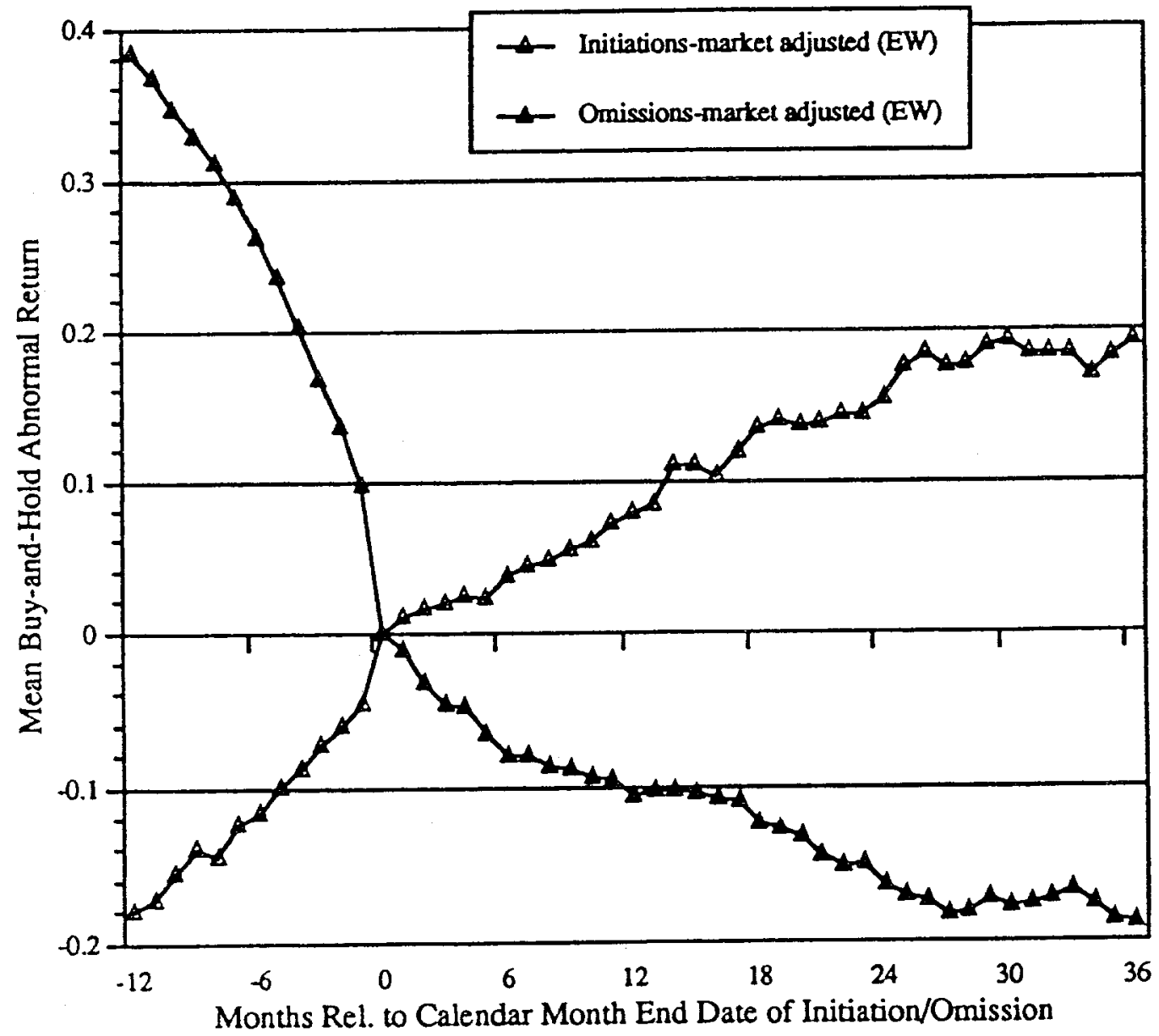




\section{Figure 2}

\section{A Naive Trading Strategy Capturing Abnormal Returns to Dividend Initiations and Omissions}

The figure displays the average return in each year to the following naive trading strategy: For a given year, buy an equal-dollar position for each dividend initiating company and sell short an equivalent dollar amount of the equal-weighted market index on the close of the first trading day after the initiation event. Likewise, sell shor similar equal-dollar positions for all dividend-omitting companies while purchasing an equivalent dollar amount of the of the equal-weighted market index on the close of the - first trading day after the omission events. Close all open positions (liquidate) by reversing the bought and sold positions on the 252nd trading day after purchase and sale. Therefore, the returns displayed below are for positions taken in the year shown, but closed out in the following year. The average return across all years is $+9.7 \%$, excluding transactions cost. The average beta across years for these portfolios is 0.16 .

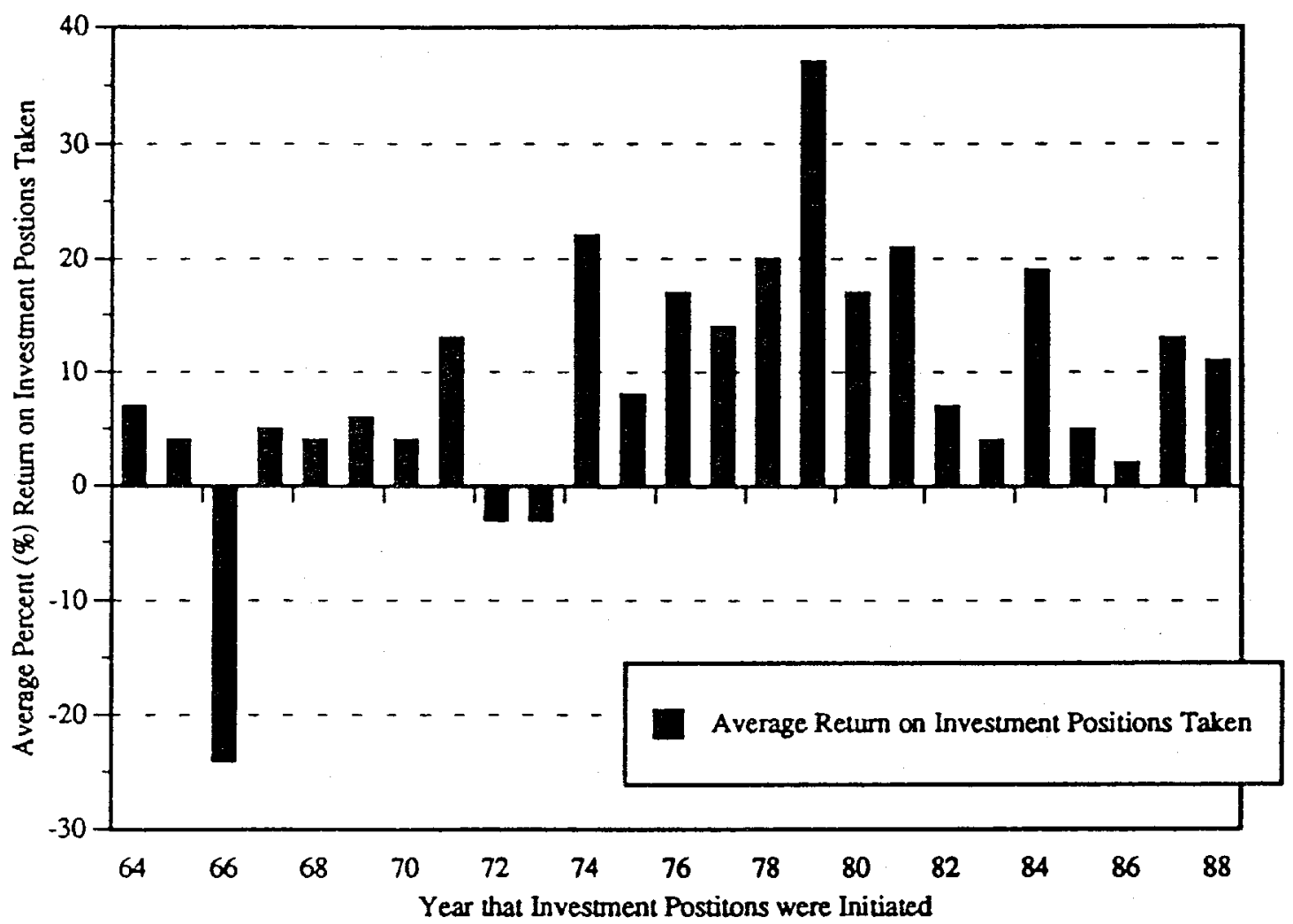


Figure 3A

Abnormal Trading Volume around Dividend Initiation

\section{Announcements}

Abnormal volume from the six months before the initiation announcements to one year after the annoucements is calculated. Normal volume is defined as the average daily tumover in day -125 to -5 relative to the event, and abnormal volume is the daily turnover minus the average daily turnover in the estimation period, relative to the daily average turnover.

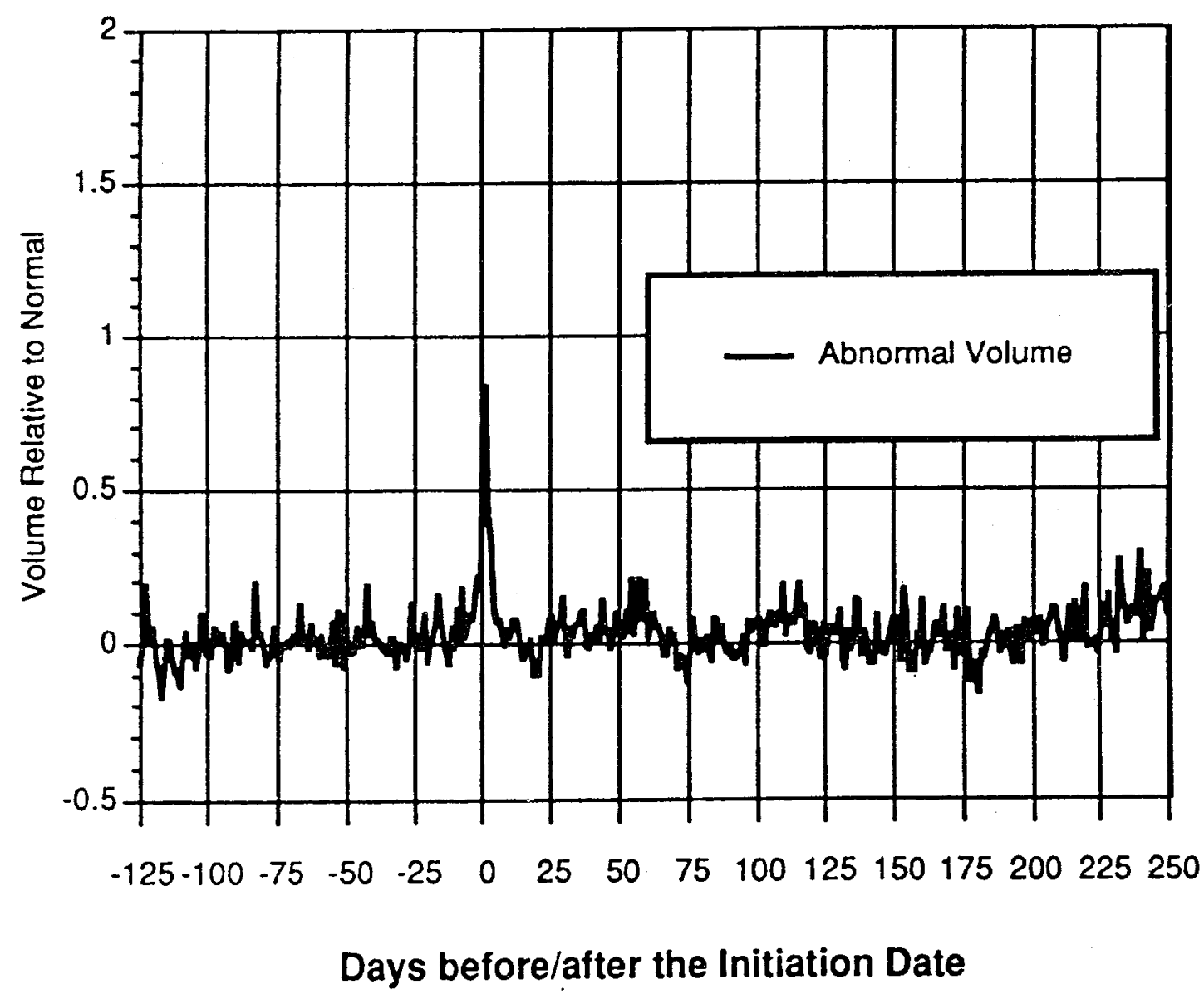


Figure 3B

Abnormal Trading Volume around Dividend Omission

Announcements

Abnormal volume from the six months before the omission announcements to one year after the annoucements is calculated. Normal volume is defined as the average daily tumover in day -125 to -5 relative to the event, and abnormal volume is the daily turnover minus the average daily turnover in the estimation period, relative to the daily average turnover.

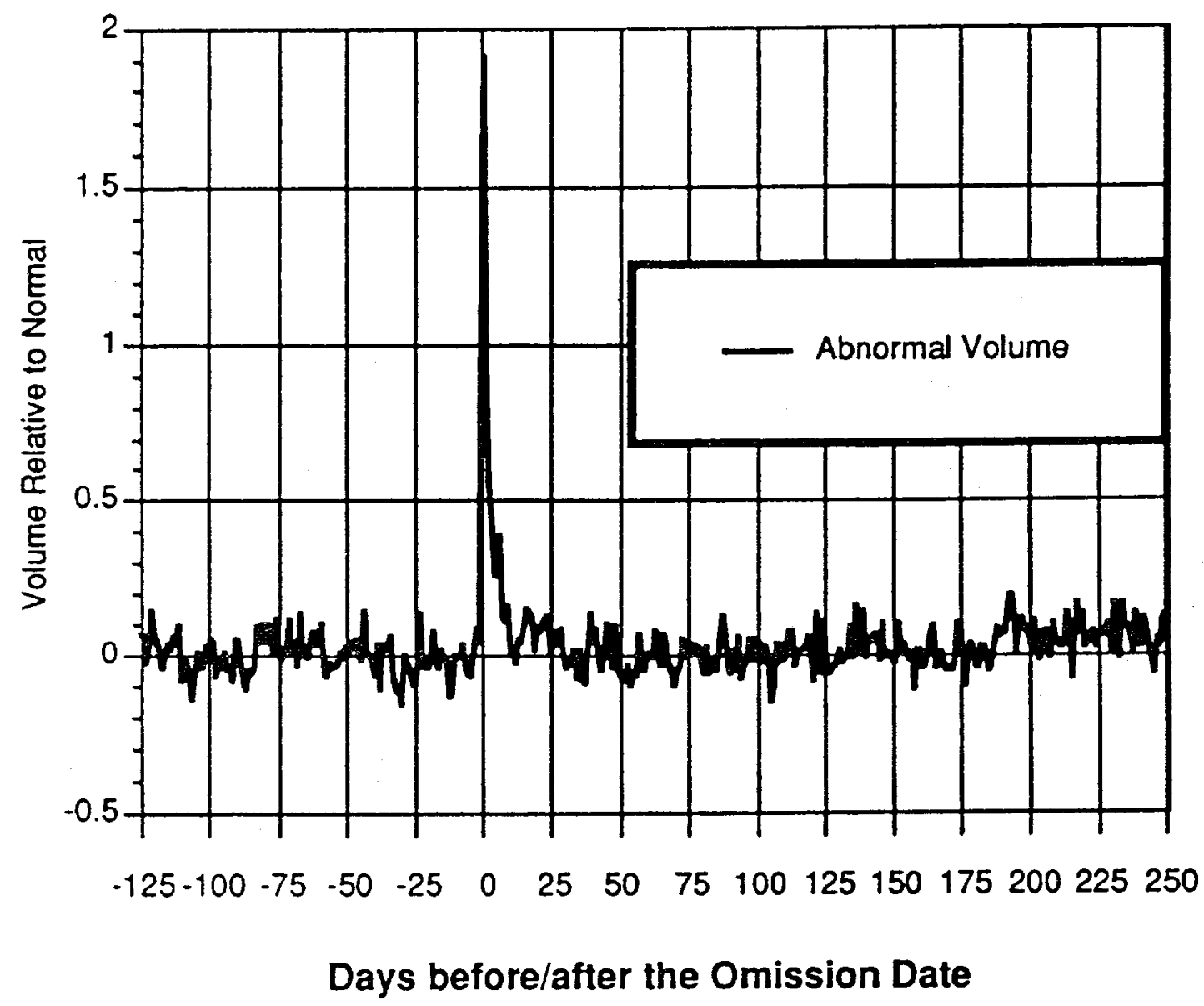

